\title{
Extramammary Paget Disease of the Vulva - Case Report
}

\section{Relato de Caso: Doença de Paget Extramamária da Vulva}

\author{
Bianca Ruschel Hillmann ${ }^{1}$ Amanda Amaro Pereira ${ }^{2}$ \\ ${ }^{1}$ Department of Gynecology and Obstetrics, Residency Program of \\ the Hospital Universitário Professor Polydoro Ernani de São Thiago, \\ Florianópolis, SC, Brazil \\ 2 Department of Pathology, Residency Program of the Hospital Universitário \\ Professor Polydoro Ernani de São Thiago, Florianópolis, SC, Brazil \\ ${ }^{3}$ Department of Gynecology and Obstetrics, Health Sciences Center, \\ Universidade Federal de Santa Catarina, Florianópolis, SC, Brazil \\ Rev Bras Ginecol Obstet 2016;38:524-528.
}

Luiz Fernando Sommacal ${ }^{3}$

\begin{abstract}
Address for correspondence Bianca Ruschel Hillmann, Division of Obstetrics and Gynecology, Hospital Universitário Professor Polydoro Ernani de São Thiago, Campus Universitário, Rua Professora Maria Flora Pausewang, s/nº Trindade. Caixa Postal 5199, 88036-800Florianópolis, SC, Brazil (e-mail: biancahillmann@gmail.com).
\end{abstract}

\begin{abstract}
Keywords

- extramammary Paget disease

- vulvar neoplasms

- pruritus vulvae

- vulvar Paget disease

\section{Resumo}

Palavras-chave

- doença de Paget extramamária

- neoplasias vulvares

- prurido vulvar

- doença de Paget vulvar

Extramammary Paget disease (EPD) is a rare malign neoplasm that may affect the vulva and has manifestations common to benign diseases such as itching, pain and eczema. This leads to delay in diagnosis and consequent worse prognosis. The definitive diagnosis is obtained by biopsy of the vulva, which shows Paget cells. The treatment of choice is wide excision with margins, which leads to sequelae, functional and aesthetic. Recurrence is common. This article reports the case of a 48-year-old female patient with history of vulvar itching for the past 2 years, who had been submitted to various treatments for benign pathologies. The patient was biopsied and was diagnosed with extensive EPD, being submitted to vulvectomy. This article aims to draw attention to the need for biopsy of pruritic vulvar lesions that do not respond to usual treatment.

A doença de Paget extramamária (DPEM) é uma neoplasia maligna incomum que pode acometer a vulva, e que tem manifestações comuns a doenças benignas como prurido, dor e eczema. Isto leva a atraso no diagnóstico e, consequente, piora do prognóstico. $\mathrm{O}$ diagnóstico de certeza se dá pela biópsia de vulva que evidencia células de Paget. $\mathrm{O}$ tratamento de escolha é a excisão com margens amplas, que leva a sequela funcional e estética. A recidiva é frequente. Este artigo relata o caso de uma paciente do sexo feminino, de 48 anos, com história de prurido vulvar há 2 anos com diversos tratamentos para patologias benignas. A biopsia da paciente confirmou diagnóstico de DPEM extensa sendo submetida a vulvectomia. Este artigo visa chamar a atenção para a necessidade de biópsia das lesões vulvares pruriginosas que não respondem ao tratamento habitual.
\end{abstract}

received

March 22, 2016

accepted

September 22, 2016

published online

November 10, 2016
Copyright $(2016$ by Thieme Publicações License terms

Ltda, Rio de Janeiro, Brazil
(요 (1) $\Theta$ 


\section{Introduction}

Extramammary Paget disease (EPD) is a rare neoplasm that occurs in areas containing apocrine glands and affects the epidermis and, occasionally, the derm. ${ }^{1-3}$ The most commonly affected site is the vulva, but it may also affect the axilla, perineum and perianal region., ${ }^{1,2}$

Vulvar Paget disease is more common from the 5th decade of life on, ${ }^{2}$ with an average age at diagnosis from 61 to 69 years, depending on the study. ${ }^{4-8}$ It is more common in Caucasians and is rare before menopause. ${ }^{6,8}$ Extramammary Paget disease accounts for less than $1 \%$ of vulvar neoplasms. ${ }^{6-8}$

The most common clinical manifestations are vulvar itching, pain and the presence of eczematous plate. ${ }^{5-8}$ Those manifestations are common to several benign diseases such as contact dermatitis, candidiasis, tinea cruris, psoriasis, lichen simplex and seborrheic dermatitis, ${ }^{2,7,9}$ thus, leading to delayed diagnosis. The diagnose occurs on average 20 months after the onset of symptoms, worsening the prognosis of patients, who will have larger lesions and higher recurrence rates. ${ }^{5,6,8}$ It is common that before diagnosis, the patient is subjected to multiple treatments with antifungal and corticoids. ${ }^{8}$ Therefore it is suggested that any vulvar lesions unresponsive to treatment be biopsied. ${ }^{2,8}$

Extramammary Paget disease may be associated with bladder, prostate, urethral, or colorectal cancer, so that the investigation of such tumors must be made once the diagnose of vulvar Paget disease is confirmed. ${ }^{2}$

Histological diagnosis of EPD is made by identification of Paget cells with abundant pale cytoplasm and large atypical nuclei with prominent nucleoli and vesicular chromatin. Staining of Paget cells is made with colloidal iron, alcian blue, mucicarmine and PAS. Immunohistochemistry can be made with markers such as the epithelial membrane antigen, carcinoembryonic antigen (CEA) and GCDFP-15. Cytokeratin 7 (CK7) and, less frequently, cytokeratin 20 , are positive and can help in the diagnosis. Immunohistochemical stains S-100 and HMB 45 are used to differentiate from malignant in situ melanoma. ${ }^{2,8}$

Extramammary Paget disease secondary to anorectal carcinoma resembles gastrointestinal glands with stratified columnar cells, signet ring cells, necrosis and intraluminal goblet cells. ${ }^{8}$

Extramammary Paget disease secondary to urothelial carcinoma resembles high-grade urothelial cells with variable shape nuclei, rough and irregular chromatin and not prominent nucleoli. Rarely the cytoplasm contains vacuoles and the signet ring cells are absent. These cells have a high rate of mitose. ${ }^{8}$

Overexpression of P53 in Paget disease is associated with underlying dermal invasion. ${ }^{8}$

Histologically, the differential diagnosis is made with Bowen disease and malignant pagetoid melanoma in situ. ${ }^{2}$ The treatment of choice is excision of the lesions with wide margins, but such treatment leads to aesthetic dissatisfaction and sequelae, and does not prevent local recurrence. Therefore, alternative treatments, such as excision without wide margins associated with radiotherapy, laser ablation, and application of imiquimod, are accepted. ${ }^{1-3,10}$ Such alternative treatments become first choice in the treatment of recurrence, and primary treatment of patients with severe clinical conditions that do not allow surgery. ${ }^{3,10,11}$

As recurrence is extremely common, even after aggressive surgery with free margins, it is widely accepted that vulvar Paget disease is multifocal, even if just in a microscopic way. ${ }^{8,9,11}$ Recurrence occurs on average 45 months after the first diagnosis, and is more common when the lesions are multifocal and surgical margins are compromised. Local recurrence developed in $44 \%$ of the patients when followed for 77 months. ${ }^{5,6}$ Still, there are reports of local recurrence 15 years after the diagnosis. ${ }^{8}$ So it is recommended that patients are followed for long periods after the treatment. ${ }^{4,5}$ As for the prognosis, the risk of death from the disease is 3 to $12 \%{ }^{5,9}$ The epidermis restricted disease has an excellent prognosis and death usually occurs by comorbidities, and not by disease. ${ }^{8}$ Invasive disease has a mortality of 13 to $18 \%$, with survival of $72 \%$ after 5 years. ${ }^{8}$ Patients with lymph node metastasis have worse prognosis with a mortality rate of $\sim 66 \%{ }^{8}$

\section{Case Report}

The subjects is a 48-year-old female patient, smoker for the past 35 years, with type 2 diabetes mellitus, in use of Metformin, and premenopausal, without using hormonal contraceptives at the moment. Patient reported vulvar itching for the past 2 years, with various treatments with creams and ointments without success. Physical examination revealed one hardened left inguinal lymph node of $\sim 1 \mathrm{~cm}$ in size. Cervix had no colposcopy abnormalities. Presence of acetowhite areas in left minora and majora labia, perineal and anterior perianal regions was detected. (-Fig. 1). Collins test was positive (-Fig. 2).

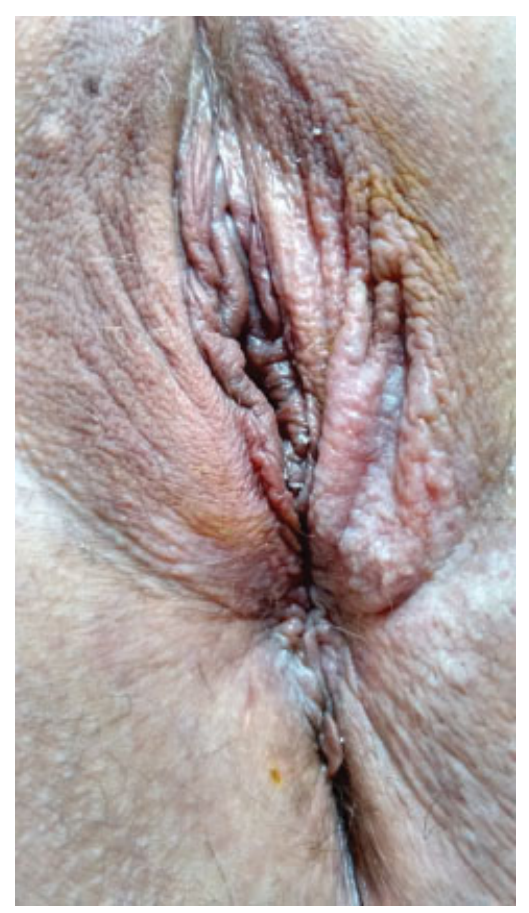

Fig. 1 Examination of the vulva with a lesion difficult to notice in the left majora and minora labia, perianal e perineal regions. 


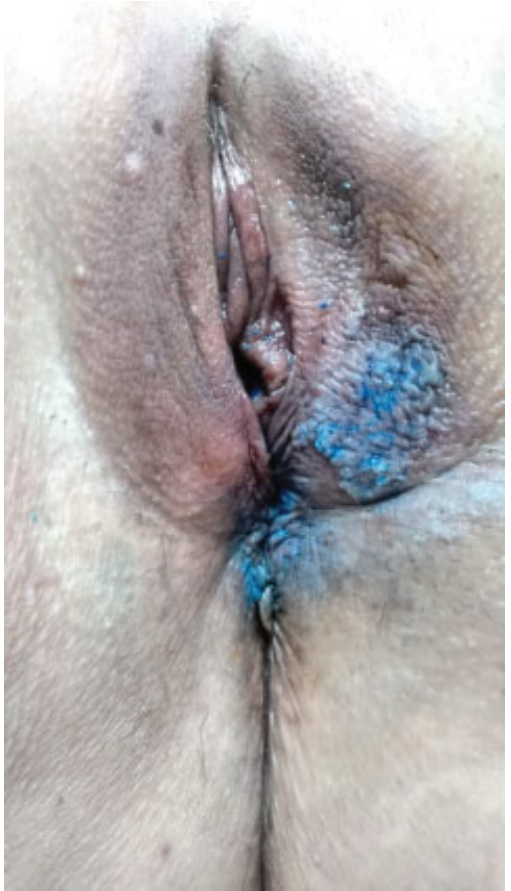

Fig. 2 Examination of the vulva with toluidine blue (Collins test) showing an extensive lesion.

A biopsy of the lesion was performed and showed infiltration of the epidermis by cells with clear abundant cytoplasm and large nuclei with pleomorphism and prominent nucleoli. These cells were distributed across the epidermal thickness, isolated or in small groups, and were more numerous in the basal layer (-Fig. 3). Immunohistochemistry showed positivity in neoplastic cells for CK7 ( - Fig. 4), CEA, and epithelial membrane antigen (EMA). The clinical and histological features were compatible with primary Paget disease of the vulva.

The disease was clinically staged as T3N1M0, and treated with radical vulvectomy and bilateral inguinal lymphadenectomy. The evaluation of the specimen ( - Fig. 5) showed no malignancy in the isolated lymph nodes and showed primary

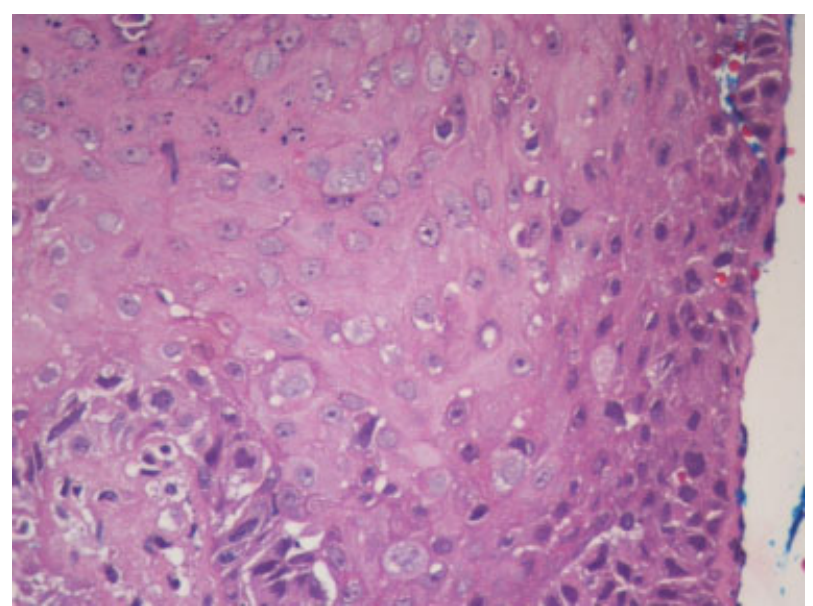

Fig. 3 Histological evaluation of vulvar biopsy with Hematoxylin eosin $400 \mathrm{X}$.

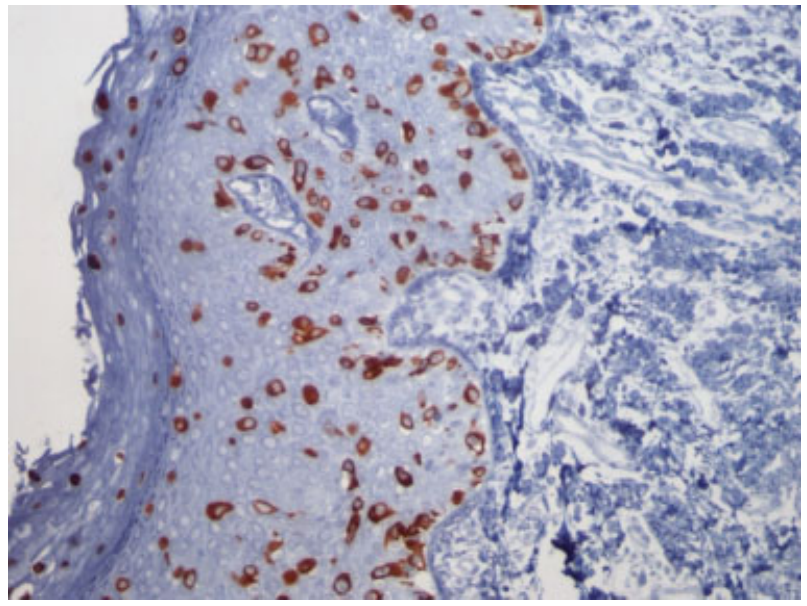

Fig. 4 Immunohistochemistry of vulvar biopsy for Cytokeratin 7.

EPD with $9 \mathrm{~cm}$ of diameter with compromised perianal margin. The patient recovered well from the surgery and will be followed for a long period at our hospital.

\section{Discussion}

As in most of the cases reported in the literature, in this one, there was a great delay in diagnosing the disease, and at the moment of diagnosis the lesion was already quite extensive, requiring treatment with radical vulvectomy and leading to aesthetic and functional sequelae.

Other than what is usually described, the patient's lesion was not eczematous and was very difficult to notice without

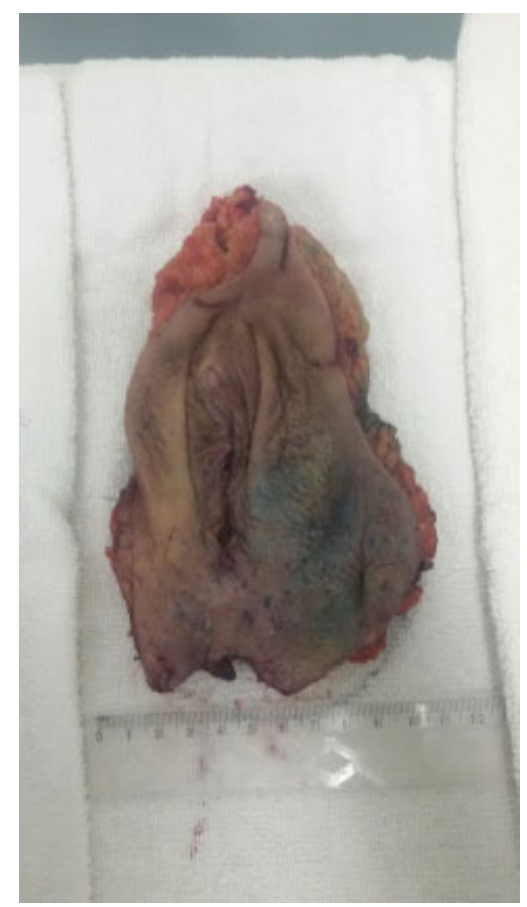

Fig. 5 Surgical specimen. 
the application of toluidine blue. This may have contributed to the delay in diagnosis.

This case reinforces the need for biopsy of all vulvar lesions that do not respond to usual treatment in a short time.

\section{References}

1 Jeon MS, Jung GY, Lee JH, Kang KW, No KW. Extramammary Paget disease of the vulva: minimal excision with adjuvant radiation treatment for optimal aesthetic results. Tumori 2015 DOI: $10.5301 /$ tj.5000394

2 Sardesai VR, Agarwal TD, Sakhalkar SP. Extra mammary Paget's disease: a rare case report. Indian J Dermatol 2015;60(1):105

3 Sanderson P, Innamaa A, Palmer J, Tidy J. Imiquimod therapy for extramammary Paget's disease of the vulva: a viable non-surgical alternative. J Obstet Gynaecol 2013;33(5):479-483

4 Nomura H, Matoda M, Okamoto S, et al. Clinicopathologic features and treatment outcomes of primary extramammary Paget disease of the vulva. J Low Genit Tract Dis 2015;19; (2):145-148
5 De Magnis A, Checcucci V, Catalano C, et al. Vulvar paget disease: a large single-centre experience on clinical presentation, surgical treatment, and long-term outcomes. J Low Genit Tract Dis 2013; 17(2):104-110

6 Shaco-Levy R, Bean SM, Vollmer RT, et al. Paget disease of the vulva: a study of 56 cases. Eur J Obstet Gynecol Reprod Biol 2010; 149(1):86-91

7 Gavriilidis P, Chrysanthopoulos K, Gerasimidou D. Extramammary Paget's disease of the vulva. BMJ Case Rep 2013; DOI: 10.1136/bcr-2013-200623

8 Delport ES. Extramammary Paget's disease of the vulva: An annotated review of the current literature. Australas J Dermatol 2013;54(1):9-21

9 Qi Y, Hu J, Sun C, Zhang J, Liu Q. Extramammary Paget's disease: analysis of 17 Chinese cases. Indian J Dermatol Venereol Leprol 2014;80(2):129-133

10 Boulard C, Duval Modeste AB, Boullie MC, Marpeau L, Courville P, Joly P. [Cryosurgery and photodynamic therapy for the treatment of Paget's disease of the vulva: two cases]. Ann Dermatol Venereol 2013;140(4):282-286French

11 Barmon D, Kataki AC, Imchen L, Sharma JD. Extra mammary Paget's disease of the vulva. J Midlife Health 2012;3(2):100-102 